\title{
Small and Medium Scale Enterprises' Activities and Eonomic Developmemnt in Obio-Akpor Local Government Area, Rivers State, Nigeria
}

\author{
Ukamaka P. Chidume \\ Simeon G. Nenbee \\ Department of Economics, \\ Faculty of Social Sciences, \\ University of Port Harcourt, \\ Port Harcourt, Nigeria
}

DOI: https://doi.org/10.36941/mjss-2022-0o11

\begin{abstract}
This paper assesses the impact of Small and Medium Scale Enterprises (SMEs) activities on economic development in Obio-Akpor Local Government Area of Rivers State, Nigeria. To achieve this theme, an instrument Called Small and Medium Scale Enterprises Survey Questionnaire (SMEQ) was developed which focused more on employment generation and poverty reduction. The population of the study was chosen based on the two thousand six hundred and thirty-four (2634) registered SMEs with the Rivers State Ministry of Commerce and Industry in 2019. Based on simple random sampling technique, a total of three hundred and thirty-eight (338) respondents were sampled. Relying on descriptive statistics and logistic regression estimation techniques, the data were analyzed. Analyses of the respondents' opinion suggest that the major businesses engaged in the study area were restaurant, tailoring and beauty/hair dressing. Again, majority of the respondents were of the opinion that SMEs operators do not have increased access to basic socialeconomic amenities. The output of the logistic regression result has it that an increase in firm size can improve the chances of SMEs fostering economic development in Obio-Akpor while increase in the salary of employees could also enhance the chances of SMEs to redress the rising poverty level too. The paper thus recommends that employment tax incentives should be granted to proprietors of SMEs and taming of the rising insecurity cases across the country.
\end{abstract}

Keywords: SMEs, Employment Generation and Poverty Reduction

\section{Introduction}

The quests to stern developmental strides of national economies remain focal objectives of many developing nations of the world. In Nigeria, despite the presence of huge, natural and human resources, there seem to be prevalence of socio-economic problems such as low per capita income, rising poverty, unemployment, income inequality, high mortality rate, lack of basic infrastructural facilities, political instability and insecurities still persist. NBS (2016), Orija and Folawewo (2019) noted that between 2004 and 2010, about eight million Nigerians were poor and the trend has continued to rise despite numerous government policy measures.

It follows that, small and medium enterprises could serve as veritable tools in the hands of most 
Emerging Economies to attain socio-economic development as demonstrated by the Asian Tigers such as: Malaysia, Taiwan, and Indonesia. These crop of hitherto industrial giants have culminated into a significant proportion of business growers globally and play less than second fiddle in global exports, employment generation, standard of living improvement and thereby, contributing significantly to national productivity of several countries (OECDs,200o).Thus, SMEs activities are therefore fundamental for economic development. In a broad view of World Bank (2013), the undeniable role of employment generation which in real terms reduces as well as eliminating regional dichotomy between urban and rural centres are one of main contributions of SMEs; and it constitutes a worthy prime mover for industrialization, economic growth and development. This is achievable through meaningfully involvement in economic diversification and increase in industrial outputs. The attainment of the core objectives of economic development indicators such as employment generation, poverty alleviation, equitable distribution of income as well as utilization of domestically sourced raw materials and indigenous technical skill aides the avenue for self-dependence (Akingunola, 2011). Muritala et al (2012), Kadiri (2012), Eze \& Okpala (2015) are of the view that in a developing country like Nigeria, the impactful effect of SMEs on economic growth and development can be in numerous forms like enhancement of local raw materials utilization, employment generation, growth of entrepreneurship, etc.

However, The concerted efforts of government authorities in Nigeria towards promoting SMEs based activities in Nigeria and subsequent contribution of SMEs to the economy have not been able to pull the populace out of extreme poverty $(40 \%$ / almost 83 million people live below poverty line)and high rate of unemployment (23.1\%) as reported by NBS (2019).

SMEs are stifled by multiple taxation and poor infrastructures such as bad networking roads, railways, tunnels, constant power and water. Inability to assess credits from financial institutions due to neck-cutting collateral has discouraged many SMEs from executing their business ideas and also weakens business expansion in the country (Olanrewaju, 2018). Thus, the objective of this paper is to ascertain whether SMEs activities have impacted on the development of Obio-Akpor L.G.A, Rivers State, Nigeria. The paper is structured in 5 sections. Sections 1 and 2 contained the introduction while Section looked at the methods of analysis. In sections 4 and 5, the paper presented the analysis of results and conclusion.

\section{Literature Review}

In extant economic literature, there seems to be numerous ways of defining small businesses. This is because people view it in relation to diverse economic based activities like asset base, capital availability of a business, annual turnover, number of employees, profit profile and more. However, this paper adopts the view of the Central Bank of Nigeria (CBN, 2010) and Small and Medium Enterprises Development Agency of Nigeria (SMEDAN, 2017) definitions. The CBN's (2010) report defines SMEs as any business with asset base of between five hundred million naira and staff strength of between 11 to 300 people. Furtherance to the CBN's (2010), SMEDAN (2017) maintained that SMEs are businesses with ten to fourth nine people and an annual turnover of five to fourth nine million naira while medium scale enterprises has fifty to one hundred and ninety nine employees with a year turnover of fifty to four hundred and ninety nine million naira.

The concern from the CBN (2010) and SMEDAN (2017) definitions are that countries' development trajectories could be enhanced using functional SMEs. This is even more visible when economic development (Howell, et al; 2011) is defined as the development of economic wealth of countries, regions or communities for the well being of their habitants as expressed in the quality of life, by creating and retaining jobs, growing income base and more.

Attempts to link economic activities and development have continually engaged the thoughts of economists and policy makers over the centuries. These ideas are captured in the theoretical postulations of the Entrepreneurship and Innovation Theory (EIT) and Entrepreneurship and Economic Incentives Theory (EEIT). 
The EIT was developed by Joseph Alois Schumpeter (1883-1950). Schumpeter assumes among several others that if there exist adequate of capital, existence of the developed banking system to avoid capital shortage, adequate advanced technology and broad private initiative, entrepreneurs would help the process of development in an economy. Thus, without any iota of doubt, innovation will enhance the introduction of new products, methods of production and opening of new markets.

The EEIT assumptions were highlighted in the works of Papanek (1962) and Harris (1970). In these works, they assumed that economic incentives are the integral factors that have induced entrepreneurial initiatives. Thus, to propel development economic incentives, link between economic gains and the inner urge, there are enhancing factors to undertake diverse entrepreneurial initiatives.

The assumptions about the theories above point to the fact that SMEs need to provide their products and services and impact on economic development. The outcome of this observation perhaps is at the root of numerous empirical literatures today to validate the significance of SMEs on economic growth and development. One example is Sanusi \& Hamza (2017) who examined the impact of SMEs on economic development: Asian countries (Malaysia, Indonesia, Singapore, Philippines, Thailand, India, China, Republic of Korea, Vietnam, Mongolia, Kazakhstan, Cambodia, Myanmar, United Arab Emirates, Oman, Qatar and Saudi Arabia). Convenience sampling was used to obtain the sample size needed for the study. Descriptive Statistics, Pearson moment correlation coefficient and multiple linear regression methods were employed as the tool for statistical analysis. The findings showed that Small Medium Enterprises (SMEs) have positive and significant impact on unemployment and export, negative and significant effect on gross domestic product and foreign direct investment. The study recommended that future research can enquire into the GDP and foreign direct investment found to be insignificant in this study.

Yaregal (2018) analyzed the role of small and medium scale enterprises in poverty alleviation. The study employed descriptive statistics techniques. The study revealed that SMEs are veritable vehicles for poverty reduction but hampered by numerous challenges and problems which include lack of access o finance, lack of infrastructure, lack of training in entrepreneurial and management skills, lack of information on business opportunities, etc. The study recommends for continuous improvement and restructuring of programs targeted at alleviating poverty through increase in capital expenditure on economic, social and community services and qualitative would alleviate poverty in Nigeria.

Gebregizabher \& Akeem's (2019) assessment of the role of SMEs in the Local Economic Development (LED) was conducted at South Africa. Data were collected through self-administered questionnaires and the use of random sampling. From the results, it was indicated that SMEs play a vital role in local economic development in South Africa. The study concluded that SMEs contribute to employment creation, wealth creation, poverty alleviation and income generation. Hence, the study therefore recommends support for SMEs by the local government; private sector and civil society should be enhanced in order to increase the contribution of SMEs to local economic development.

Manzoor, Longbao \& Mohammad (2019) examined the role of small and medium enterprises on poverty alleviation in South Asian Association for regional Cooperation (SAARC) founded in 1985 via Panel Data Analysis. The fixed effect method (FEM) and multiple regression models were used to analyze the observed data. The results indicated that growth in the SME has a positive and an appreciable positive impact on poverty alleviation. The study concluded that government of respective countries should concentrate on the promotion of sustainable economic growth, price stability and employment generation to control poverty. The study recommends that macroeconomic issues like unemployment, poverty, income inequalities and slow economic development may be resolved with collective efforts and coordination among member countries.

Weldeslassie, Claire, Kibron \& Negasi (2019) curiously examined the contributions of micro, small and medium enterprises (MSMEs) to income generation, employment and GDP: Case study Ethiopia. A survey method was used to collect data. Qualitative and quantitative approaches were used to analyze the collected data. The study revealed that MSMEs in Ethiopian are the chief sources 
of job, income, significantly contribute to the local, regional and national GDP and key policies to eliminate poverty. Also, the study revealed that major obstacles of MSEMs in Ethiopia are question of sustainability, lack of credit, weak market linkage, insufficient training, weak human resource development schemes, dependency on government and spoon-feeding mentality among others. The study concluded that access to credit facility is the key determinants of MSEMs performance and capital size strongly determine their survival. The study recommends that growth of MSEMs needs to be further strengthened as it enhances employment and poverty reduction.

Gamo \& Gollagari's (2020) study focused on the role of local government in supporting MSMEs performance: The case of Ethiopia. The study employed a mixed method approach using both quantitative and qualitative data. Document analysis, narrative analysis, and descriptive statistics was used to analyze the data. The result showed low level of employment and capital generation of MSMEs due to ineffective local government support. The study concluded that MSMEs should be enhanced in the local area to attract investment and create employment to reduce the heavy burden placed on larger cities by accommodating the ever-increasing population of the region. The study therefore recommends local government institutions should create a conducive local business environment to attract more investment and promote the existing firms' performance.

Mahumud, Minda \& Ebrahim's (2020) work centered on the role of micro and small enterprise in employment creation and income generation in Samara-Logia Town, Afar Regional State. The study adopted a descriptive cross-sectional research design. Questionnaire and interview were used as data collection instruments and the response obtained was analyzed using descriptive statistical tools such as tables, percentages. The study revealed that the growth rate of Medium and Small scale Enterprises (MSEs) in Samara-logia town contributed significantly to employment creation and income generation. Also, the study revealed that major constraints hindering MSEs are financial shortage and inability to get access to affordable rental house. The study concluded that MSEs have great contribution in reducing unemployment and in providing income to the owners and employees of MSEs. The study recommended that MSEs should access to credit given its vital role in growing MSEs and would help MSEs to produce and sell products easily.

Anthony et al (2020) researched on small and medium enterprises as a strategy for employment generation in Nigeria, using selected manufacturing companies in Delta state. The descriptive research design was of relevance for use and data were analyzed using the standard acceptable analytical software in Social Sciences (SPSS) version 21.Meanwhile, $\mathrm{t}$

In attempt to retrieved analyzed data results, statistic such as, Mean, frequency, percentage and One-way Analysis of Variance (ANOVA) were employed. Anthony et al (2020) categorically summarized the results as "having revealed significant relationship between small and medium enterprises product branding and marketing, finance, policies and problems, and employment generation in Nigeria". The study further perceived sophisticated marketing techniques as efficient way of ensuring competitiveness.

Tolulope \& Olokundan (2018) studied the impact of SMEs on economic development, with data evidence from transiting economy. A descriptive research design was used to obtain data from a cross section of respondents in 6o domestically sited enterprises located in different chosen states of Nigeria "2o in Lagos State; 20 in Anambra State; and 20 in Kano State of Nigeria respectively". "Data was collected with a structured questionnaire and descriptive analytical method, alongside parametric technique". "The output of the result suggests a significant interaction between the small and medium-scale enterprises and economic development in developing nations". Conclusively, SMEs poses as a vital mover of economic development, especially in Nigeria. Furthermore, the core mandate of engaging in policies and programmes that births SMEs will enable job creation abilities for the nation- Nigeria.

In a similar study, John \& Muogbo's (2018) paper re-emphasized the role of SMEs on poverty eradication in Nigeria.Primarydata alongside research questionnaire aimed at analyzing the research questions. Whereas, Chi-square statistic served as method of study metrics for hypothesis; drawing from about fifty sample spaces. In that work, SMEs provided vacancies for employment, training 
grounds and capacity utilization of local resources.

Kowa, Olusegun \& Olalekan (2019) using variants of analytical approaches includingANOVA, and administration of questionnaire to sample about 142 companies registered under SMEDAN, to model the contribution of SMES on poverty eradication in Nigeria. The study employed statistical tools of Chi-square and ANOVA and suggested sound strategic developmental framework forSMEs in order to grow to large-scale capital intensives. The empirical studies reviewed have focused on importance of SMEs on job creation, poverty reduction and standard of living as an indicator of economic development which are in different local government areas and states in Nigeria.

\section{Gap in Reviewed Literature}

Drawing from the above discussions, the theoretical framework for this paper rests on entrepreneurial and innovation theory. This is because the theory shed lights on the need of entrepreneurial and innovative drive of SMEs as it's critical to economic development in developing economy like Nigeria. Again, at the empirical front, Previous empirical studies reviewed has focused on impact of SMEs on job creation, poverty alleviation and standard of living as an indicator of economic development( See Abeh; 2017, John \& Muogbo; 2018, Obi, Ibidunni, Tolulope \& Olokundan; 2018, Kowa, Olesugun \& Olalakan; 2019). None of these studies viewed the effect of SMES on economic development in Obio/Akpor Local Government Area, Rivers State, Nigeria. More specifically, this paper measured the performance of SMEs using two variables (business expansion and sales growth) and also captures economic development using two variables (poverty reduction and employment generation). Previous studies employed statistical techniques of Chi-square and ANOVA which is limited in determining the magnitude of the impact of independent on the proxy of economic development and thereafter applied the qualitative regression technique of (logit regression) with advantage of determining the magnitude of regressors on the identified measures of economic development.

\section{Materials and Methods}

\subsection{Study Area}

Obio-Akpor is a Local Government Area (L.G.A.) is in the metropolis of Port-Harcourt. She is one of the major centers of economic activities in Nigeria, and a major city in the Niger Delta region. ObioAkpor is bounded by Port-Harcourt to the south, Oyigbo and Eleme Local Government Areas to the east, Ikwere and Etche Local Government Areas to the north and Emohua to the west. It is located between latitudes $4^{\circ} 45^{\prime} \mathrm{N}$ and $4^{\circ} 60^{\prime} \mathrm{N}$ and longitude $6^{\circ} 50^{\prime} \mathrm{E}$ and $8^{\circ}$ oo' $\mathrm{E}$ covering an area of approximately $260 \mathrm{~km} 2$, has a low land area with average elevation below 30 meters above sea level and at the 2006 census held a population of 464,789. It consists of 17 electoral wards with its headquarters at Rumuodomaya. The original indigenous occupants of the area are the Ikwerre people (Wikipedia, 2020).

\subsection{Population and Sample Size Determination}

The target population was based on the Central Bank of Nigeria's( CBN) survey template for operators and registered SMEs from the Rivers state from the Rivers State Ministry of Commerce, Trade and Industry(RSMCTI) in 2021. The total population of SMEs operators in Obio/Akpor were estimated to be two thousand six hundred and thirty four (2634). They were the entire number of employees of SMEs that registered with the Nigerian Association of Small Scale Industrialists in Rivers State. Thereafter, a Simple random sampling technique was adopted to draw the number of respondents. This was the basic probability sampling design used. It was used in studying a relatively small finite population which is homogenous. Thereafter, the Taro Yamane's formula was used to 
obtain the sample size. This is demonstrated as follows: ${ }^{n=\frac{N}{1+N(e)^{2}}}$ Where; $\mathrm{n}=$ sample size; $\mathrm{N}=$ population size; $\mathrm{e}=$ level of precision required; $\mathbf{1}=$ constant .

In determining the sample size, the following variables were used: Confidence interval $=95 \%$;

$\mathrm{e}=$ margin of error $=0.05 ; n=$ Substituting into the formula, $n=\frac{2634}{1+2634(0.05)^{2}} n=\frac{2634}{1+2634(0.0025)} n=$ $\frac{2634}{1+6.585} n=347$ (sample size).

Thereafter, a total of three hundred and forty-seven (347) copies of questionnaire were distributed to SMEs operators in Obio-Akpor.

\subsection{Nature and Sources of Data}

This study relied on both primary and secondary resources for collection of required data. Questionnaire, interviews and observations formed the primary sources of data generated whereas publications and journals constituted the secondary sources of data.

\subsection{Method of Data Collection}

The primary data required for the study was obtained through the use of structured questionnaire to prospective respondents. The instrument was Called Small and Medium Scale Enterprises Survey Questionnaire (SMEQ). The SMEQ question items were divided into two broad sections-I and II. Section I covers the socio-demographic aspect of the prospective respondents such as gender, age among others. Section II focused on issues relating to small and medium scale enterprises on economic development in Obio-Akpor. The responses to the specific questions drawn from the research questions formed the basis of analysis. The questions in the questionnaire were based on a five-point Likert scale type. Required responses ranging from one to five as: Strongly Disagree (SA)-1 point, Disagree (D)-2 points, Undecided (UD)-3 points, Agree (A)-4 points, and Strongly Agree (SA)-5 points. A 'Yes or No' with values ranging between 1 and $o$ was used.

\subsection{Reliability and validity of Research Instruments}

In order to establish the reliability of the instrument, the researchers conducted a pilot study. The test-retest method of assessing reliability was used which involve administering the same instrument twice to the same group of subjects after a carefully considered time lapse between the first and second test administered. The researcher used Cronbach Alpha formula to calculate the coefficient of the alpha value. The validity of data was based on content validity. The summary of the result of the reliability test using the Cronbach Alpha method revealed that the items of firm size (o.8o1) and salary (o.750) hence; considered reliable. The acceptance was based on the fact that the respective alpha values were above the minimum of 0.7 (or 70 percent).

\subsection{Techniques of Data Analysis}

The study employed qualitative and quantitative analysis. The qualitative methods were based on interviews. Descriptive tools such as tables and percentages were used to analyse in detail the obtained data. To estimate the role of SMEs on economic development in Obio-Akpor, the researchers also used Discrete Response Model to explain the role of each of the selected variables on the dependent variables. The Discrete Response technique was applied because of the responses of the dependent variables are binary and involve a non-linear estimation. The study used the Logistic regression instead of the Ordinary Least Square (OLS) because the qualitative responses were nonnormal and therefore, the linear estimators such as OLS are not applicable particularly when dealing with small samples. More specifically, the error terms of qualitative response models tend to exhibit 
heteroscedasticity. Thus, the application of OLS will bias the standard errors and hence inferential statistics using the errors such as the $t$-values will be invalid. Thus, the Logit model was employed to resolve the highlighted problems inherent in the use of linear estimators highly debated in literature as relate to binary choice models (See Greene 2003:665). Thus, the Logit regression model is expressed in the form: $\operatorname{Pr}(Y=\mid X)=g\left(\beta_{0}+\beta_{1} X_{1}+\beta_{2} X_{2}+\cdots+\beta_{n} X_{n}\right)$ (1) Where:

The equation above defines the conditional probabilities of $Y=1$ (i.e. $Y$ occurring) given $X$.

$\mathrm{Y}=$ Dependent variables ( poverty reduction, employment generation)

$\mathrm{X}=$ Explanatory Variables ( in this study the explanatory variables are log of business expansion, $\log$ of sales growth)

$\operatorname{lnBE}=$ Log of Business Expansion

$\operatorname{lnSG}=$ Log of Sales Growth

POV = Poverty Reduction

EMPL $=$ Employment Generation

$\beta_{0}, \beta_{1}, \beta_{2}, \ldots,, \beta_{n}$, are paremeter estimates

For a more compact representation of equation (1), we have: $\operatorname{Pr}\left(Y=\left.\right|_{X}\right)=g(X \beta)(2)$

In the Logit regression model, $\wedge(X \beta)$ can be expressed as: $\wedge(X \beta)=\frac{\exp (X \beta)}{1+\exp (X \beta)}$ (3)

Equation (4) is the cumulative (logistic) distribution function (cdf) and it ranges between zero and one for all values of $(X \beta)$.The basic assumptions about equation (3) is that

$\wedge$ is a non-linear function of $(X \beta)$ and hence, we cannot use OLS and the errors follow standard logistic distribution leading to the use of the Maximum Likelihood estimator in Qualitative Response Models. These assumptions called for the estimation of the parameters of Odds ratios, Log of odds and Marginal effects and Conditional Probability in our model. Here, Odds Ratio is defined as the ratio of probability of $\mathrm{Y}=1$ to the probability that $\mathrm{Y}=0$. This is given as: $\exp (X \beta)=\frac{\wedge(X \beta)}{1-\wedge(X \beta)}(4)$

The analyses of the various equations stated above are built in STATA Statistical Package and STATA Statistical Package version 16.0 was used estimation.

A Mathematical Illustration of the problem centred on how variables, such as SMEs (business expansion, Sales growth) impact on economic development proxied by poverty reduction and employment generation. The response variable FIN, YES/NO, is a binary variable.

The model can be expressed as follows: $Z=\beta_{0}+\beta_{1} \overline{\ln B E+} \beta_{2} \ln S G$ (5)

Where: $\ln B E=$ mean of business expansion and $\ln S G=$ mean of sales growth

\section{Results and Discussions}

\subsection{Data Presentation}

A total of three hundred and forty seven (347) copies of questionnaire were distributed of which only 338 were retrieved. The retrieval rate for the distributed copies of questionnaire were broken down and portrayed in the Table 1.

Table 1: Questionnaire Response Rate Analysis

\begin{tabular}{|l|c|c|}
\hline Category of Administered Questionnaire & Frequency & Percentage \\
\hline Total Number of Distributed Questionnaire (TNDQ) & 347 & $100 \%$ \\
\hline Number of Questionnaire Fully Completed and Returned (NQFCR) & 338 & $97.40 \%$ \\
\hline Number of Questionnaire Retrieved but Not Fully Completed (NQRNFC) & 6 & $1.736 \%$ \\
\hline Number of Questionnaire not Retrieved & $3(0.87 \%)$ & \\
\hline \multicolumn{1}{|c|}{ Total } & 347 & $\mathbf{1 0 0} \%$ \\
\hline
\end{tabular}

Source: Field Survey (2021)

Table 1 gives the response rate of the respondents regarding the questionnaire administered to 
respondents. From a total of three hundred and forty seven (347) copies of questionnaire administered, only three hundred and thirty eight (338) copies of questionnaire were fully completed and returned, giving a retrieval rate of 97.4 percent. Out of the total 347 issued questionnaire, a total of six $(1.73 \%)$ was not fully completed while $3(0.87 \%)$ was not retrieved. These categories jointly constitute about $2.6 \%$. The inability of the researchers and their assistants to retrieve them were due largely to time, limited financial resource base of the researchers, fear of COVID-19 exposure by respondents, etc. despite these challenges, the paper relied on the $338(97.4 \%)$ response rate for the analyses.

\subsection{Empirical Data Analysis}

5.2.1 Analysis of Socio-demographic Attributes of the Respondents.

Table 2: Distribution of Gender of Respondents

\begin{tabular}{|l|l|c|c|c|c|}
\hline \multicolumn{2}{|c|}{} & Frequency & Percent & Valid Percent & Cumulative Percent \\
\hline \multirow{4}{*}{ Valid } & Male & 103 & 30.5 & 30.5 & 30.5 \\
\cline { 2 - 6 } & Female & 235 & 69.5 & 69.5 & 100.0 \\
\cline { 2 - 6 } & Total & 338 & $\mathbf{1 0 0 . 0}$ & $\mathbf{1 0 0 . 0}$ & \\
\hline
\end{tabular}

Source: Authors' Computation (2021)

Table 2 shows that majority of the respondents were female totaled 235 representing 69.5 percent while male stood at 103 which corresponds to 30.5 percent.

Table 3: Distribution on Educational Qualification of Respondents' Educational Qualifications

\begin{tabular}{|c|c|c|c|c|c|}
\hline & Frequency & Percent & Valid Percent & Cumulative Percent \\
\hline \multirow[t]{5}{*}{ Valid } & No formal education & 79 & 23.4 & 23.4 & 23.4 \\
\hline & Primary education & 84 & 24.9 & 24.9 & 48.2 \\
\hline & Secondary education & 127 & 37.6 & 37.6 & 85.8 \\
\hline & Tertiary education & 48 & 14.2 & 14.2 & 100.0 \\
\hline & Total & 338 & 100.0 & 100.0 & \\
\hline
\end{tabular}

Source: Authors' Computation (2021)

Table 3 shows respondents with highest education is secondary totaled 127 , followed by primary 84 , no formal education 79 and tertiary 48 .

Table 4: Opinions about the Distribution of Years of Business Experience Years of Business Experience

\begin{tabular}{|l|l|c|c|c|c|}
\hline \multicolumn{2}{|c|}{} & Frequency & Percent & Valid Percent & Cumulative Percent \\
\hline \multirow{4}{*}{ Valid } & $1-5$ years & 74 & 21.9 & 21.9 & 21.9 \\
\cline { 2 - 6 } & $6-10$ years & 139 & 41.1 & 41.1 & 63.0 \\
\cline { 2 - 6 } & $11-15$ years & 83 & 24.6 & 24.6 & 87.6 \\
\cline { 2 - 6 } & 16 and above & 42 & 12.4 & 12.4 & 100.0 \\
\cline { 2 - 6 } & Total & 338 & 100.0 & 100.0 & \\
\hline
\end{tabular}

Source: Authors' Computation (2021)

Table 4 shows the summary information on the years of business experience of the respondents. According to Table 4, a total of 74 respondents, corresponding to 21.9 percent, have business 
experience within the range of $1-5$ years. 139 respondents out of the 338 respondents have been in their respective business ventures for about 6 - 10 years. Those with business experience of about $11-$ 15 years amounted to 83, representing 24.6 percent of the aggregate 338 respondents. As seen from the Table 4, a total of 42 respondents, corresponding to 12.4 percent, have garnered business experience of about 16 years and above.

Table 5: Type of Businesses

\begin{tabular}{|l|c|c|}
\hline Type of Business & Frequency & Percentage \\
\hline Boutique & 27 & 8.0 \\
\hline Recording Studios & 8 & 2.4 \\
\hline Electrical repairs, accessories and maintenance & 34 & 10.1 \\
\hline Cold Room & 23 & 6.8 \\
\hline Restaurant & 57 & 16.9 \\
\hline Night \& Drinking Bars & 25 & 7.4 \\
\hline Tailoring Shop & 31 & 9.2 \\
\hline Timber & 10 & 3.0 \\
\hline Hair Dressing & 31 & 9.2 \\
\hline Phone Technicians & 23 & 6.8 \\
\hline Furniture & 19 & 5.6 \\
\hline Painting Firm & 8 & 2.4 \\
\hline Poultry/Fish Farm & 12 & 3.6 \\
\hline Pharmacy/Super Store Total & 13 & 3.8 \\
\hline Others & 17 & 5.0 \\
\hline & 338 & 100 \\
\hline
\end{tabular}

Source: Authors' Compilation from Field Survey Data (2021)

Table 5 shows that restaurant, electrical repairs, accessories and maintenance, tailoring shop and hair dressing shop are the top four rank businesses engaged in by the respondents. The summary table for different class of business under study.

\subsubsection{Analysis of Respondents' Opinions about SMEs and Poverty Reduction}

Table 6: Univariate Data Analysis

\begin{tabular}{|l|c|c|c|c|c|c|c|c|}
\hline Questions & SA & A & UD & D & SD & Mean & SD & Decision \\
\hline SMEs business expansion have reduced poverty & 78 & 183 & 13 & 39 & 25 & 3.74 & 1.154 & Accept \\
\hline SMEs sales growth have improved the standard of living & 65 & 159 & 9 & 73 & 32 & 3.45 & 1.279 & Accept \\
\hline $\begin{array}{l}\text { Significant contribution of SMEs have led to access to basic social- } \\
\text { economic amenities such as clean water and nutritious food }\end{array}$ & 34 & 87 & 4 & 165 & 48 & 2.69 & 1.274 & Reject \\
\hline SMEs business expansion have created job opportunities & 27 & 69 & 17 & 140 & 85 & 2.45 & 1.282 & Reject \\
\hline SMEs sales growth have improved the welfare of the citizens & 26 & 58 & 12 & 149 & 93 & 2.33 & 1.258 & Reject \\
\hline $\begin{array}{l}\text { Significant contributions of SMEs have reduced social vices such } \\
\text { as armed robbery, kidnapping }\end{array}$ & 36 & 51 & 19 & 145 & 87 & 2.42 & 1.305 & Reject \\
\hline
\end{tabular}

Note: Options: "SA-Strongly agree", "A-Agree","UD- Undecided", "D- Disagree", "SD- Strongly disagree".

Source: Authors' Computation (2021)

5.2.3 Analysis of Opinions of Respondents about SMEs and Poverty Reduction using the Estimated Logit Model

The two models of employment generation and poverty are estimated using the logit regression 
technique and reported in Table 7 and 8 respectively. The interpretation of the results follows the odds ratio, logs of odds and marginal effects. The effect of firm size and salary on economic development in Obio/Akpor L.G.A, Rivers State was the focus of the estimation.

Table 7: Expressed Opinions about Effect of firm Size and Salary on Employment Generation

\begin{tabular}{|l|c|c|c|}
\hline Variables & \multicolumn{3}{|c|}{ Coefficients } \\
\hline & Odds Ratio & Log of odds & Marginal effect $(d y / d x)$ \\
\hline $\ln \boldsymbol{F M Z}$ & $3.5239^{* * *}$ & $1.2595^{* * *}$ & $0.2385^{* * *}$ \\
\hline $\boldsymbol{l n}$ Salary & 0.9994 & -0.0005 & -0.0001 \\
\hline $\boldsymbol{C}$ & $1.63 \mathrm{e}^{-08^{* * *}}$ & $-17.932^{* * *}$ & \\
\hline
\end{tabular}

Source: Authors' Computation (2021)

Table 7 gives the impact of firm size and salary on employment generation in Obio/Akpor L.G.A, in Rivers State. The respondents were of the opinion that an increase in the number of person engaged by small and medium scale enterprise owners in Obio/Akpor will increase the chances of economic development in Obio/Akpor. The odds ratio of firm size is positive, indicating that the probability of small and medium scale enterprise bringing about economic development in Obio/Akpor will increase by 3.5239. The associated coefficient of the parameter estimate is less than 0.05. hence, the study reject the null hypothesis and conclude that an increase in firm size does increase the chances of small and medium scale enterprises accelerating economic development in the study area. This finding validates those of Abeh (2017), Sanusi \&Hamza (2017), Edoko, Agbasi \& Ezeanolue (2018), Hadded, Muhammad, Imat \&Rahmat (2019) and Muhumud, Minda \&Ebrahim (2020) that SMEs promote economic development.

In contrast, as documented in Table 7 , the odds ratio of salary is 0.9994 , implying that an increase in salary by one unit will increase the probability of small and medium scale enterprises fostering economic development in Obio/Akpor. The estimated coefficient is found to be statistically insignificant, the study fail to reject the null hypothesis of small and medium scale enterprises has no significant on employment generation in Obio/Akpor.

Table 8: Expressed Opinions about Effect of Firm Size and Salary on Poverty

\begin{tabular}{|l|c|c|c|}
\hline Variables & \multicolumn{3}{|c|}{ Coefficients } \\
\hline & Odds Ratio & Log of odds & Marginal effect $(d y / d x)$ \\
\hline $\ln \boldsymbol{F M Z}$ & $0.95^{6} 3$ & -0.0445 & -0.0105 \\
\hline $\boldsymbol{l n S a l a r y}$ & $1.0186^{* * *}$ & $0.0184^{* * *}$ & $-0.0043^{* * *}$ \\
\hline $\boldsymbol{C}$ & $1.67 \mathrm{e}^{* 0} 8^{* * *}$ & $-17.9082^{* * *}$ & \\
\hline
\end{tabular}

Source: Authors' Computation (2021)

Table 8 contains the outcome of the estimation of the effect on firm size and salary on poverty in Obio/Akpor L.G.A, Rivers State, Nigeria. The coefficient of the odds ratio of firm size is positive and calculated to be 0.9563 . From the result, an increase in the firm size of small and medium scale enterprises in Obio/Akpor local government area will increase the probability of SMEs reducing poverty by 95.63 percent or 0.9563 . The associated probability value shows that the increased effect of firm size is statistically insignificant at the 5 percent level of significance. Thus, the study fail to reject the null hypothesis which indicates that small and medium scale enterprises has no significant impact on poverty reduction in Obio/Akpor. 
The odds ratio of salary is 1.0186 indicating that an increase in salary of employees of small and medium scale enterprises in the Obio/Akpor will drastically improve the probability of reducing poverty among individuals in the study area by about 1.86 percent or 1.0186. From the result in Table 8 , the coefficient is found to be statistically significant at even the one (1) percent level of significance. Following this, the study fail to accept the null hypothesis, concluding that increase in staff salary of small and medium scale enterprises operational in the study area will increase the chances of reducing poverty in Obio/Akpor local government area, Rivers State. Our finding aligns with those of Umogbai, Diana \&Ekeh (2016), John \&Muogbo (2018), Yaregal (2018), Kowa, Olusegun \& Olalekan (2019) and Manzoor, Longbao \& Mohammad (2019) who found that SMEs can reduce poverty. Our finding have both theoretical and policy implications. In terms of theory, our findings empirically validates Schumpeter's hypothesis which argues that small and medium enterprises can help drive economic development. The findings of this study is of importance in terms of economic policies as it reveals that government can achieve the goal of economic development by designing and implementing policies that can promote small and medium enterprise operations and enable the setup of new one.

\section{Conclusion and Recommendations}

SMEs have been identified as a contributor to actualizing economic prosperity and achieving socioeconomic development as expressed by the respondents. SMEs are at the heart of any healthy economy as their activities bring about innovations, touch on new frontiers and increase domestic production. It is for this purpose that the SMEs impact on economic development in Obio/Akpor was examined. The result of the analysis conducted using the qualitative response model showed that increases in firm size and salary of staff can increase the probability of SMEs contributing the economic prosperity and development but most of the SMEs operators in Obio/Akpor L.G.A were female with secondary school education certificates and have operated their businesses between 6 to 10 years. These businesses were mostly restaurants, hair dressing, tailoring, cold room boutiques, etc. The study concludes, on the basis of these discoveries that, SMEs are critical in the process of economic development and prosperity. Thus, the paper suggests that the third tier of government of Rivers state should incentivize SMEs owners by granting them employment incentives, wherein they enjoy some tax rebate in the event their staff strength exceed a minimum threshold. Again, the local government authorities should liaise with relevant security personnel to eradicate crime and other social vices in the; by so doing create favourable environment for business to thrive.

\section{References}

Abeh, O. (2017). Small and medium scale enterprises (SMEs) as a strategy for employment generation in Nigeria: A study of selected manufacturing companies in Delta state of Nigeria. International Journal of Scientific Research in Education, 10(2), 156-168.

Akingunola, R. O. (2011). Small and medium enterprises and economic growth in Nigeria: An assessment of financing options. Pakistan Journal of Business and Economic Review,2(1); 78-98.

Anthony, E. H., Kashim, A. \& Ibrahim, R. (2020). Impact of Government Policy and Insecurity Factors on Small and Medium Enterprises (SMEs) Productivity in Nigeria, European Journal of business and management Research.1(1),PP 4.

Emmanuel, M., \&Johnbusco, C. O.(2018). Geospatial Mapping and Analysis of Public Health Care Facilities in Obio/Akplor L.G.A, River State. International Journal of Advanced Geosciences.

Evolutionary History of Obio-Akpor(2020).In wikipedia.https://en.m.wikipedia.org/wiki/Obio-Akpor.

Greene, W. H (2003). Econometric Analysis. $5^{\text {th }}$ ed . new Jersey: Pearson education, Inc.

John, A. C.\& Muogbo, U. S. (2018).Role of small and medium enterprises in poverty eradication in Nigeria.European Journal of Research and Reflection in Management Sciences, 6(2), 2018.

Kowo, S. A., Olusegun, A. O., \&Olalekan, O. S. (2019).The role of SMEs development on poverty alleviation in Nigeria." Insights Into Regional Development, 1 (3): 214-226.

National Bureau of Statistics Report.(2019). Nigeria unemployment and poverty profile.2019 Abuja. 
NBS (2016). Nigeria poverty Report. Available at: www.nigeriastat.gov. retrived on 20/10/2017.

Obi, J., Ibidunni, A. S., Tolutope, A., \&Olokundan, M. (2018) . Contribution of small and medium enterprises to economic development: Evidence from a transiting economy. data in brief; 18 (2018), pp. 835-839.

Olanrewaju,R. (2018). Stars business retrieved from www.stearsng.com:https//www.stearsng.com/articles/is it now easy to do business in Nigeria//.

Organisation for Economic Co-operation and Development (OECD).(200o). Small and medium scale enterprises: Local strength, global reach OECD. policy review. pp. 1-8

Orija, O. A. \& Folawewo, A. O. (2019). Does Human capital matter for FDI's Effect on poverty? Evidence from Nigeria. Selected Paper for the 2019 NES Conference held at Abuja, Nigeria.

World Bank. (2013). The world bank annual report 2013. Washington, DC. 